\title{
Why are mineralocorticoid receptor antagonists cardioprotective?
}

\author{
Wenxia Chai • A. H. Jan Danser
}

Received: 11 July 2006 / Accepted: 29 August 2006 / Published online: 31 October 2006

(C) Springer-Verlag 2006

\begin{abstract}
Two clinical trials, the Randomized ALdosterone Evaluation Study (RALES) and the EPlerenone HEart failure and SUrvival Study (EPHESUS), have recently shown that mineralocorticoid receptor (MR) antagonists reduce mortality in patients with heart failure on top of ACE inhibition. This effect could not be attributed solely to blockade of the renal MR-mediated effects on blood pressure, and it has therefore been proposed that aldosterone, the endogenous MR agonist, also acts extrarenally, in particular in the heart. Indeed, MR are present in cardiac tissue, and possibly aldosterone synthesis occurs in the heart. This review critically addresses the following questions: (1) is aldosterone synthesized at cardiac tissue sites, (2) what agonist stimulates cardiac MR normally, and (3) what effects are mediated by aldosterone/MR in the heart that could explain the beneficial effects of MR blockade in heart failure? Conclusions are that most, if not all, of cardiac aldosterone originates in the circulation (i.e., is of adrenal origin), and that glucocorticoids, in addition to aldosterone, may serve as the endogenous agonist of cardiac MR. MR-mediated effects in the heart include effects on endothelial function, cardiac fibrosis and hypertrophy, oxidative stress, cardiac inotropy, coronary flow, and arrhythmias. Some of these effects occur via or in synergy with angiotensin II, and involve a non-MRmediated mechanism. This raises the possibility that aldosterone synthase inhibitors might exert beneficial effects on top of MR blockade.
\end{abstract}

W. Chai · A. H. J. Danser $(\bowtie)$

Department of Pharmacology,

Room EE1418b, Erasmus MC, Dr. Molewaterplein 50,

3015 GE Rotterdam, The Netherlands

e-mail: a.danser@erasmusmc.nl
Keywords Aldosterone - Mineralocorticoid receptor . Cortisol $\cdot$ Non-genomic $\cdot$ Inotropy $\cdot$ Arrhythmia

\section{Introduction}

The renin-angiotensin-aldosterone system (RAAS) has been viewed conventionally as a circulating system, involved in the regulation of salt, fluid homeostasis and blood pressure. Kidney-derived renin cleaves liver-derived angiotensinogen to form angiotensin (Ang) I in circulating blood (Fig. 1). Angiotensin-converting enzyme (ACE), located at the luminal side of the endothelium, subsequently converts Ang I to Ang II. Ang II exerts its effects via stimulation of Ang II type $1\left(\mathrm{AT}_{1}\right)$ and type $2\left(\mathrm{AT}_{2}\right)$ receptors. Besides acting as a vasoconstrictor via $\mathrm{AT}_{1}$ receptors, Ang II also stimulates the formation of the sodium-retaining hormone aldosterone. Aldosterone mediates its cellular effects by binding to the mineralocorticoid receptor (MR), a member of the steroid/thyroid/retinoid/orphan receptor family of transcription factors.

This classic concept has been updated in the past two decades. It is now believed that some or all of the components of the RAAS are synthesized locally in tissues such as the heart and vessel wall (Danser 2003; Tom et al. 2003). For instance, in the heart, Ang II is synthesized locally by cardiac ACE following uptake of renin and angiotensinogen from the circulation (Danser et al. 1994; van Kats et al. 1998). This Ang II subsequently stimulates cardiac $\mathrm{AT}_{1}$ and $\mathrm{AT}_{2}$ receptors (Batenburg et al. 2004; van Kats et al. 2000). Local synthesis of Ang II at cardiac tissue sites is in agreement with the observation that the beneficial effects of ACE inhibitors in heart failure are, at least in part, 


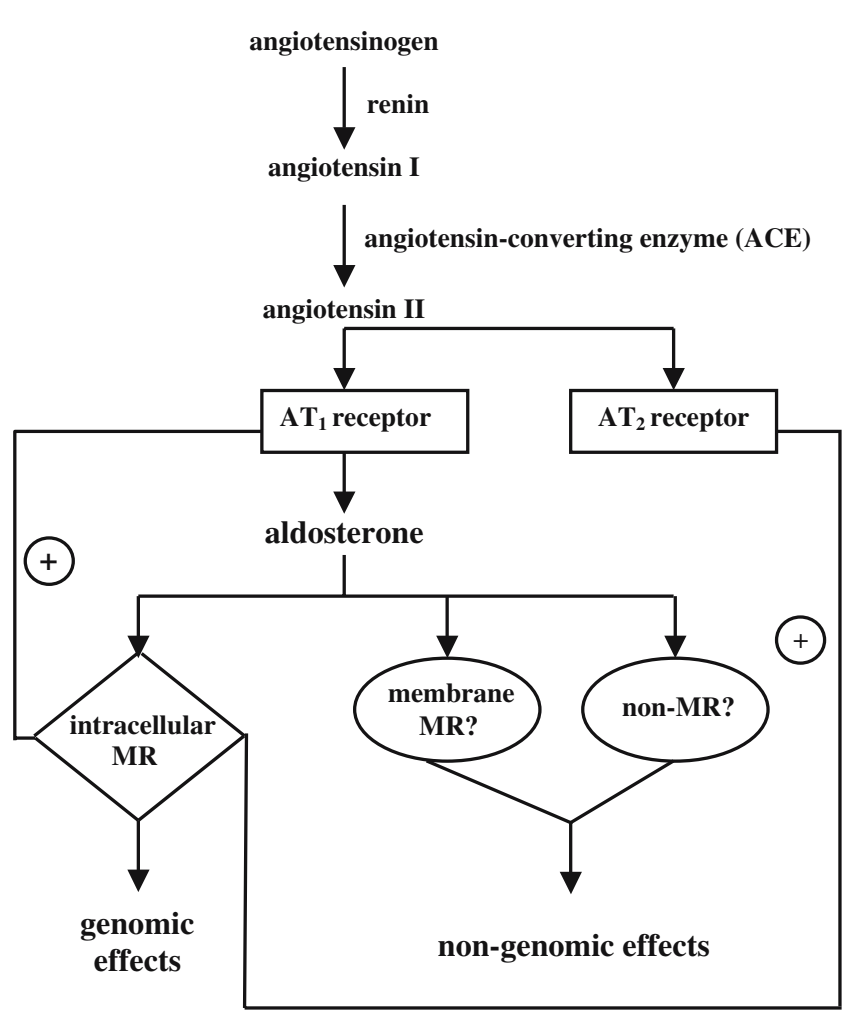

Fig. 1 The renin-angiotensin-aldosterone system. Angiotensin II activates angiotensin II type 1 and type $2\left(\mathrm{AT}_{1}\right.$ and $\left.\mathrm{AT}_{2}\right)$ receptors. $\mathrm{AT}_{1}$ receptor activation in the adrenal results in the synthesis and release of aldosterone, which subsequently exerts 'genomic' (after hours, involving protein synthesis) or 'non-genomic' (within minutes, not involving protein synthesis) effects through either mineralocorticoid receptors (MR) or other, as yet unidentified, receptors. MR may occur both intracellular and on the cell membrane. Aldosterone upregulates both $\mathrm{AT}_{1}$ and $\mathrm{AT}_{2}$ receptors, and $\mathrm{AT}_{1}$ receptor activation also results in MR stimulation in an aldosterone-independent manner

independent of their effect on blood pressure (Yusuf et al. 2000).

Traditionally, treatment of heart failure and hypertension has been performed mainly on the basis of the reninangiotensin system (RAS) rather than the RAAS, with the assumption that aldosterone will be suppressed once Ang II formation is blocked. However, aldosterone formation does not stay suppressed during prolonged RAS blocking therapy. After 3 months of therapy, aldosterone levels start to rise again and they continue to do so due to "Ang II reactivation" or "aldosterone escape" (Farquharson and Struthers 2002; Jorde et al. 2002).

Two clinical trials, the Randomized ALdosterone Evaluation Study (RALES) (Pitt et al. 1999) and the EPlerenone HEart failure and SUrvival Study (EPHESUS) (Pitt et al. 2003), have convincingly indicated that MR antagonists reduce mortality in patients with heart failure and systolic left ventricular dysfunction post-myocardial infarction on top of ACE inhibition. In particular, a reduction in the rate of sudden death was observed. These results draw attention to the importance of aldosterone as an independent risk factor in the pathophysiology of cardiovascular disease. The benefit of MR antagonists during RAS blockade is not yet fully understood. Their effects cannot be attributed solely to blockade of the renal MR-mediated effects on blood pressure (Pitt et al. 1999, 2003), and it is now generally assumed that aldosterone also acts extrarenally, in agreement with the concept of local RAAS.

Indeed, MR have been demonstrated in the heart, both at the mRNA and protein level (Lombès et al. 1995). Importantly, the enzymes required for the synthesis of aldosterone appear to be expressed in the human heart as well (Young et al. 2001). Together with the fact that Ang II is capable of increasing the aldosterone levels in isolated rat hearts and blood vessels (Silvestre et al. 1998; Takeda et al. 1997), these data suggest that aldosterone, like Ang II, may be formed and act locally in the heart. This review addresses the following questions: (1) is aldosterone really synthesized at cardiac tissue sites, (2) what agonist stimulates cardiac MR, and (3) what effects are mediated by aldosterone/MR in the heart that could explain the beneficial effects of MR blockade in heart failure?

\section{Aldosterone synthesis at cardiac tissue sites?}

Aldosterone, a steroid that was originally discovered in 1953, is secreted by the zona glomerulosa cells of the adrenal cortex. The kidney is the major target for adrenal aldosterone to increase sodium (and consequently water) reabsorption and potassium excretion. The production of aldosterone is regulated at two critical enzyme steps: (1) the formation of pregnenolone from cholesterol by the mitochondrial enzyme P450scc (side-chain cleavage), and (2) the conversion of corticosterone to aldosterone by cytochrome P450 11ß-hydroxylase 2 (CYP11B2, 'aldosterone synthase'). Aldosterone synthesis in the adrenal cortex is regulated by Ang II, potassium and, more weakly, sodium and adrenocorticotrophic hormone.

Extra-adrenal aldosterone synthesis has been proposed in heart (Silvestre et al. 1998), brain (Gomez-Sanchez et al. 1997) and vessel wall (Takeda et al. 1995, 1997). The rat heart expresses the steroidogenic acute regulatory (StAR) protein and aldosterone synthase, although at 100 -fold lower levels than the adrenal (Casal et al. 2003; Silvestre et al. 1998). The StAR protein facilitates intramitochondrial cholesterol transfer, the rate-limiting step of steroidogenesis. Aldosterone synthase expression has also been proposed in the human heart (Tsybouleva et al. 2004; Young et al. 2001). In support of the functional importance of such expression, net release of aldosterone was observed across the human coronary vascular bed (Nakamura et al. 2004). However, other studies demonstrated the opposite (i.e., cardiac aldosterone extraction) (Hayashi et al. 2003), whereas it 
was also noted that, in humans, cardiac aldosterone correlated closely with the cardiac levels of renin. Since the latter is exclusively of renal origin (i.e., blood-derived) (Danser et al. 1994, 1997; Saris et al. 2001), its correlation with aldosterone argues against independent aldosterone synthesis at cardiac tissue sites. Furthermore, recent careful studies in rats, paying great attention to the measurement of aldosterone in cardiac tissue, did not confirm the idea of local synthesis of aldosterone in the rat heart (Fiebeler et al. 2005; Gomez-Sanchez et al. 2004). In these studies, the cardiac aldosterone levels were much lower than previously reported by others (Silvestre et al. 1998). Furthermore, the cardiac levels correlated closely with the plasma levels of aldosterone, and they decreased to levels at or below the detection limit after adrenalectomy.

Subsequent perfusion studies with aldosterone in the isolated Langendorff heart (Chai et al. 2006) showed that the steroid rapidly accumulated in cardiac tissue, not only in extracellular (interstitial) fluid but also in a second, as yet unidentified, compartment. At steady state, the aldosterone tissue levels (expressed per g wet weight) were higher than its levels in coronary effluent (expressed per $\mathrm{ml}$ ). Washout from the second compartment occurred relatively rapid (half life $<10 \mathrm{~min}$ ), suggesting that it represented cell surface-bound rather than internalized aldosterone (Fig. 2). This pattern resembles that of cardiac renin, which also accumulates in extracellular fluid and binds to membrane receptors (Danser et al. 1994; de Lannoy et al. 1997; Saris et al. 2001). After prolonged washout, cardiac aldosterone became undetectable. Thus, on the one hand, the heart

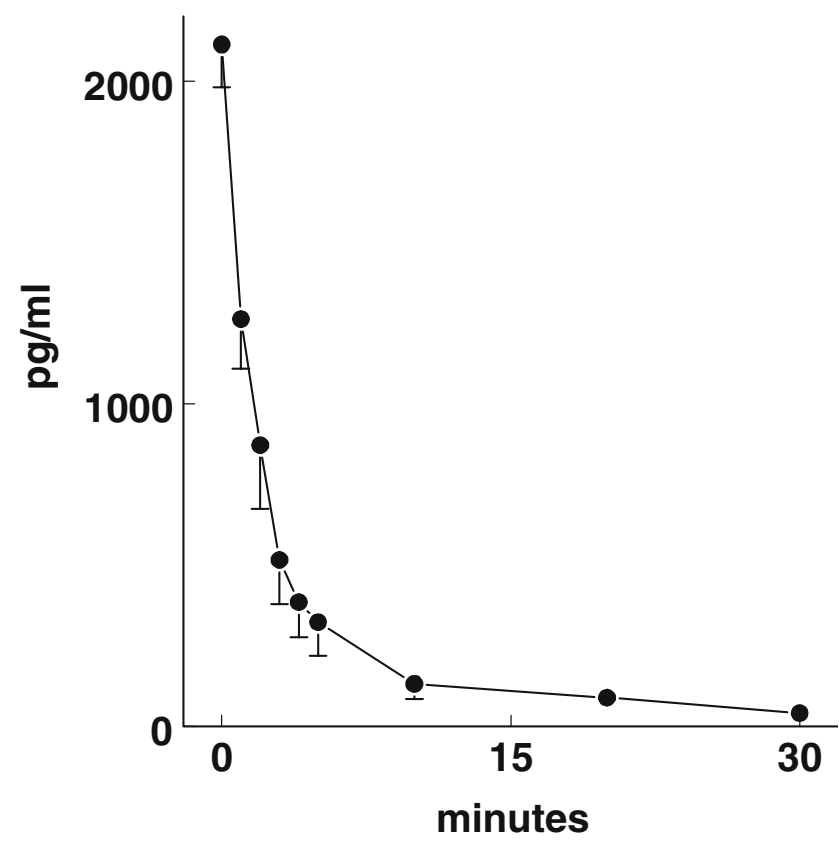

Fig. 2 Washout of aldosterone from the isolated perfused rat Langendorff heart after its exposure to $10 \mathrm{nmol} / 1$ aldosterone for $30 \mathrm{~min}$. Data are modified from Chai et al. (2006) displays a large capacity to accumulate aldosterone. This explains why the levels of cardiac aldosterone in rats can be up to 10-fold higher than in serum (Fiebeler et al. 2005). On the other hand, cardiac aldosterone disappears rapidly during perfusion with aldosterone-free buffer. This provides an explanation for the 'release' of aldosterone across the coronary vascular bed in humans and rats (Takeda et al. 2000). The majority of cardiac aldosterone, if not all, is however derived from the circulation, i.e., is not synthesized locally, both under normal and pathological conditions (Chai et al. 2006; Fiebeler et al. 2005; Gomez-Sanchez et al. 2004).

\section{Activation of cardiac mineralocorticoid receptors by aldosterone?}

MRs occur both in $\mathrm{Na}^{+}$-transporting epithelia (e.g., kidney, colon) and non-epithelial tissues such as brain (de Kloet et al. 2000), heart (cardiomyocytes) (Lombès et al. 1995), and blood vessels (endothelial and smooth muscle cells) (Lombès et al. 1992; Oberleithner 2005; Oberleithner et al. 2004). The presence of MR in the cardiovascular system has been confirmed both at the mRNA and protein level in animals as well as in humans (Lombès et al. 1992).

MRs bind mineralocorticoids and glucocorticoids with equal affinity $\left(\mathrm{K}_{\mathrm{d}} \approx 0.5-2 \mathrm{nM}\right.$ ) (Arriza et al. 1987; Lombès et al. 1994). Yet, the circulating concentrations of glucocorticoids are several orders of magnitude higher than those of aldosterone (Fig. 3). Selectivity of aldosterone binding to MR is achieved by co-expression of $11 \beta$-hydroxysteroid dehydrogenase type 2 (11ßHSD2) (Alzamora et al. 2000). This enzyme converts cortisol (the endogenous glucocorticoid in humans) and corticosterone (the endogenous glucocorticoid in rats) to their non-MR-binding metabolites cortisone and 11-dehydrocorticosterone (Fig. 3). In addition, the off-rate of aldosterone from the MR is five times lower than that of glucocorticoids (Lombès et al. 1994), and thus it is possible that MR also discriminate aldosterone from glucocorticoids, at least in part, independently of $11 \beta$ HSD2.

In the kidney, $11 \beta$ HSD2 expression is high enough to allow selective MR stimulation by aldosterone. In contrast, in the heart, the $11 \beta$ HSD2 levels are almost negligible (Nagata et al. 2006), and it has therefore been proposed that cardiac MR are occupied by cortisol/corticosterone rather than aldosterone (Funder 2005b; Gomez-Sanchez et al. 2004; Nagata et al. 2006). In fact, the endogenous glucocorticoid levels are high enough to keep all cardiac MR permanently occupied (Funder 2005b). Such permanent occupation does not apply to glucocorticoid receptors, since they have a $\approx 30$-fold lower affinity for cortisol/ corticosterone than MR (Fig. 3). Glucocorticoids are 
Fig. 3 Diagram illustrating activation of glucocorticoid and mineralocorticoid receptors (GR, MR) by cortisol (top) or aldosterone (bottom). Selectivity of aldosterone binding to MR is achieved by co-expression of $11 \beta$-hydroxysteroid dehydrogenase type 2 (11ßHSD2). $11 \beta$ hydroxysteroid dehydrogenase type 1 (11ßHSD1), which acts as a reductase in vivo, reactivates cortisone to cortisol. The affinity constants refer to aldosterone-MR and cortisol-GR binding (Arriza et al. 1987; Hagendorf et al. 2005; Lombès et al. 1994). Note that, in the absence of $11 \beta \mathrm{HSD} 2$, MR bind cortisol with an affinity equal to that for aldosterone

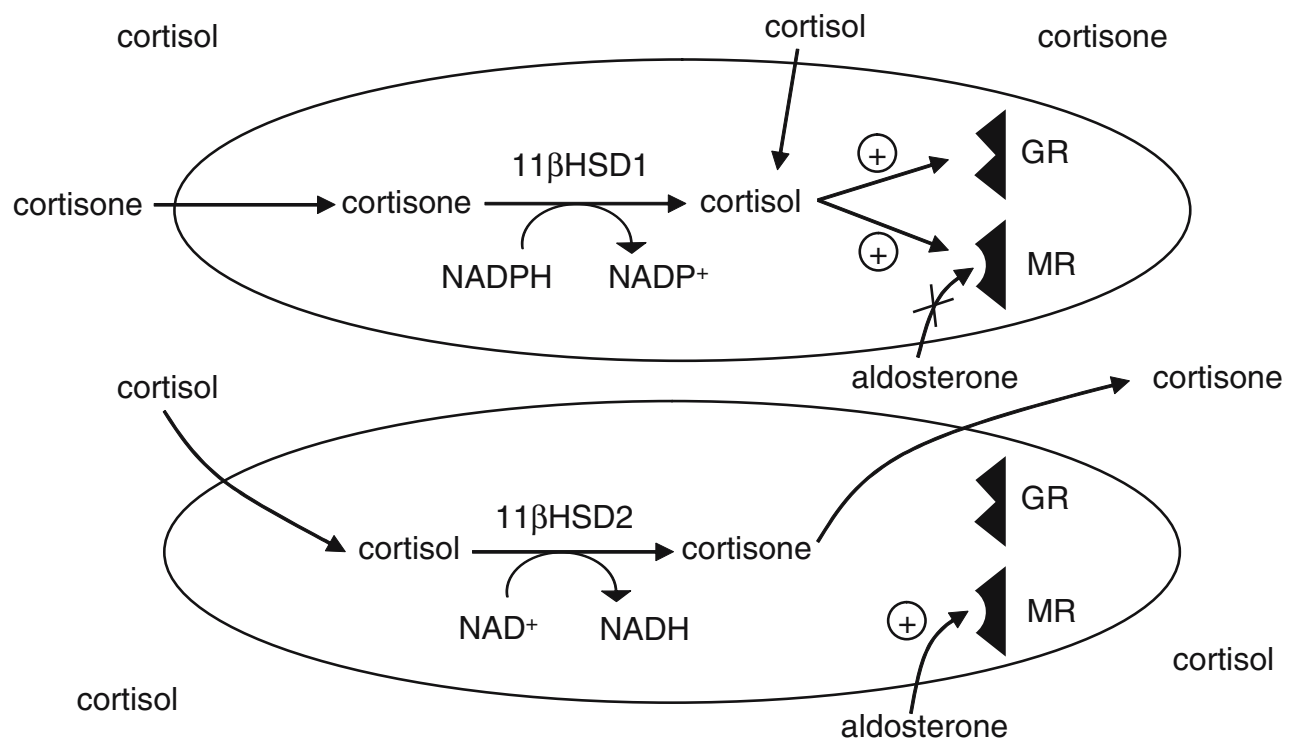

\begin{tabular}{|lll|}
\hline plasma levels $(\mathrm{nM})$ & aldosterone & $0.1-1$ \\
& glucocorticoid hormones & $10-1000$ \\
affinity constant $(\mathrm{nM})$ & GR & $0.5-2$ \\
& MR & $10-20$ \\
\hline
\end{tabular}

assumed to act as antagonists of MR (i.e., they exert no effect following binding to MR) in kidney (Good et al. 2002) and heart (Qin et al. 2003), whereas in the vessel wall, during $11 \beta \mathrm{HSD} 2$ blockade with carbenoxolone, they act as agonists (Alzamora et al. 2000). The latter could relate to the observation that glucocorticoid-MR complexes become activated as a result of the generation of reactive oxygen species (ROS). Under such circumstances, MR antagonists may exert effects by blocking the consequences of glucocorticoid-MR complex activation rather than aldosterone-MR activation (Funder 2005b; Nagata et al. 2006). The increased expression in the failing rat heart of the enzyme $11 \beta$-hydroxysteroid dehydrogenase type 1 (11ßHSD1), which reactivates 11-dehydrocorticosterone to corticosterone, further supports this concept (Nagata et al. 2006).

\section{Genomic versus non-genomic effects}

The classical MR-mediated effects of aldosterone are referred to as 'genomic' effects. These effects involve binding of aldosterone to intracellular MRs, and the translocation of the steroid-MR complex to the nucleus, where it acts as a transcriptional regulator, inducing protein synthesis (in particular synthesis of the epithelial $\mathrm{Na}^{+}$ channel) after several hours. Genomic effects can be inhibited by agents that block either transcription (e.g., actinomycin D) or translation (e.g., cycloheximide).
In addition to its genomic effects, which occur after hours, aldosterone also exerts rapid effects (within minutes) in various tissues, e.g., heart and vasculature. These effects are usually described as 'non-genomic', since they do not involve DNA-directed, RNA-mediated protein synthesis. For instance, aldosterone rapidly affects cardiac inotropy and facilitates both vasodilation and vasoconstriction (Barbato et al. 2002; Liu et al. 2003; Mazak et al. 2004; Michea et al. 2005; Mihailidou et al. 2004; Schmidt et al. 2003). In many (but not all) cases, these effects could not be blocked by the MR antagonist spironolactone, and therefore the existence of a novel (membrane-associated?) aldosterone receptor has been proposed (Funder 2005a; Wehling et al. 1995). However, despite numerous efforts in the past decade, no convincing data toward the characterization of a membrane receptor for aldosterone have been put forward (Funder 2005a; Wehling 2005). Consequently, it is not unlikely that these effects are after all also being mediated via the classical (intracellular) MR (Funder 2005a). If so, an explanation must be provided for the lack of effect of spironolactone toward the rapid aldosteroneinduced actions in vitro. Possibly, via modification or dimerization, classical MR can attain an atypical pharmacology, thereby no longer allowing the binding of MR antagonists such as spironolactone. In addition, spironolactone exerts MR-independent effects of its own, i.e., it blocks human Ether-a-Go-Go-Related gene $\mathrm{K}^{+}$channels (Caballero et al. 2003) and inhibits calcium entry (Cargnelli et al. 2001). Thus, to solve this issue, future studies should 
make use of alternative MR antagonists such as eplerenone. Eplerenone displays increased selectivity for the MR over other steroid receptors, although its affinity for the MR in vitro is 10 - to 20 -fold lower than that of spironolactone.

The rapid, non-genomic actions involve activation of the phospholipase C-protein kinase C (PKC)-inositol 1,4,5trisphosphate $\left(\mathrm{IP}_{3}\right)-1,2$ diacylglycerol (DAG) pathway, which leads to an increase in intracellular $\mathrm{Ca}^{2+}$ and stimulation of the $\mathrm{Na}^{+} / \mathrm{H}^{+}$exchanger (Barbato et al. 2004b; Funder 2005a; Liu et al. 2003; Lösel et al. 2002; Mihailidou et al. 2004; Sato et al. 1997). The latter causes a rise in intracellular $\mathrm{Na}^{+}$, which subsequently activates $\mathrm{Na}^{+} / \mathrm{K}^{+}$-ATPase. Interestingly, however, when the increase in intracellular $\mathrm{Na}^{+}$is prevented, aldosterone decreases $\mathrm{Na}^{+} / \mathrm{K}^{+}$-ATPase activity in a PKC-dependent manner (Mihailidou et al. 2004). Thus, aldosterone may exert both positive and negative inotropic effects. Other second messenger pathways that have been linked to the rapid effects of aldosterone include mitogen-activated protein (MAP) kinases, ROS and the epidermal growth factor receptor (Jaffe and Mendelsohn 2005; Mazak et al. 2004).

\section{Effects of aldosterone in the cardiovascular system}

Substantial evidence has emerged showing that aldosterone induces adverse effects in the cardiovascular system. The co-expression of $11 \beta \mathrm{HSD} 2$ and MR in human heart and blood vessels (Glorioso et al. 2005; Jaffe and Mendelsohn 2005; Lombès et al. 1995), albeit at low levels, supports the concept that these organs possess the cellular machinery required for direct aldosterone action, irrespective of the source of aldosterone.

\section{Endothelial dysfunction}

Aldosterone increases the volume and stiffness of endothelial cells and induces gap formation, allowing irregular diffusion pathways for large particles (Oberleithner 2005; Oberleithner et al. 2004). This mechanism could contribute to endothelial dysfunction observed in hyperaldosteronism. The normalization of endothelial function by spironolactone in patients with heart failure supports this concept (Abiose et al. 2004; Macdonald et al. 2004).

Oxidative stress, inflammation, fibrosis and atherosclerosis

A growing number of studies support a specific role of the MR as a mediator of oxidative stress and subsequent inflammation, fibrosis and atherosclerosis. Elevations in circulating aldosterone are accompanied by a pro-inflammatory/fibrogenic vascular phenotype (Ahokas et al. 2005; Blasi et al. 2003; Sun et al. 2002), and since this phenomenon can be blocked by both spironolactone and anti-oxidants (Sun et al. 2002), it appears that aldosterone, via MR, induces oxidative stress. Indeed, aldosterone upregulates various subunits of NADPH oxidase and induces ROS generation in mononuclear and vascular smooth muscle cells (Ahokas et al. 2005; Calo et al. 2004; Mazak et al. 2004; Sun et al. 2002). In addition, aldosterone stimulates collagen synthesis in cardiac fibroblasts (Brilla et al. 1994). Consequently, aldosterone-induced cardiac fibrosis may be due to both direct effects in the heart (mediated via fibroblasts) and indirect peripheral effects (mediated via oxidative stressactivated mononuclear cells) (Ahokas et al. 2005). The MR antagonist eplerenone inhibited atherosclerosis both in monkeys (Takai et al. 2005) and apolipoprotein-E deficient mice (Suzuki et al. 2006) fed a high-cholesterol diet, most likely by attenuating oxidative stress and inflammation.

Cardiac inotropy and coronary flow

In the isolated perfused rat Langendorff heart, aldosterone, like Ang II, rapidly increased left ventricular pressure and decreased coronary flow (Chai et al. 2005a; Moreau et al. 1996). Barbato et al. (2002) observed an increase in cardiac contractility in combination with an increase in coronary flow, but this may relate to the fact that the much larger positive inotropic effects in their study had favoured coronary vasodilation. Spironolactone and eplerenone did not block the inotropic and vasoconstrictor/dilator effects of aldosterone in the rat heart (Barbato et al. 2002; Chai et al. 2005a). In fact, spironolactone exerted similar inotropic effects on top of aldosterone (Barbato et al. 2002; Chai et al. 2005a), and thus it appears that the effects of aldosterone on inotropy and flow occur in a nonMR-mediated manner.

In human myocardial trabeculae, aldosterone induced a negative inotropic response (Fig. 4), in contrast to the wellknown positive inotropic effects of Ang II in this preparation (Chai et al. 2005b). The PKC inhibitor chelerythrine chloride, but not spironolactone or eplerenone, blocked this negative inotropic effect, suggesting that it is mediated via a non-MR in a PKC-dependent manner. The aldosterone concentrations required to induce this effect were in the high nanomolar range, i.e. a range that occurred in failing hearts only (Chai et al. 2005b). Hydrocortisone, but not 17ßestradiol, mimicked the effects of aldosterone, although at lower potency (Fig. 4). The contrast between the effects of aldosterone in the rat heart (positive inotropy) and the human heart (negative inotropy) may relate to species differences. However, there are alternative explanations. First, inotropic effects in isolated trabeculae do not necessarily parallel inotropic effects in intact hearts, since the latter also reflect responses on coronary flow (Barbato et al. 2002). Second, similar diametrically differing effects of aldosterone have 
Fig. 4 Inotropic effects of aldosterone, hydrocortisone and $17 \beta$-estradiol in human atrial trabeculae. Left panel original tracing from an experiment with aldosterone (numbers represent $\log$ [aldosterone] in $\mathrm{mol} / \mathrm{L}$ ). Right panel \% change from baseline contractile force. Data have been obtained from Chai et al. (2005b)

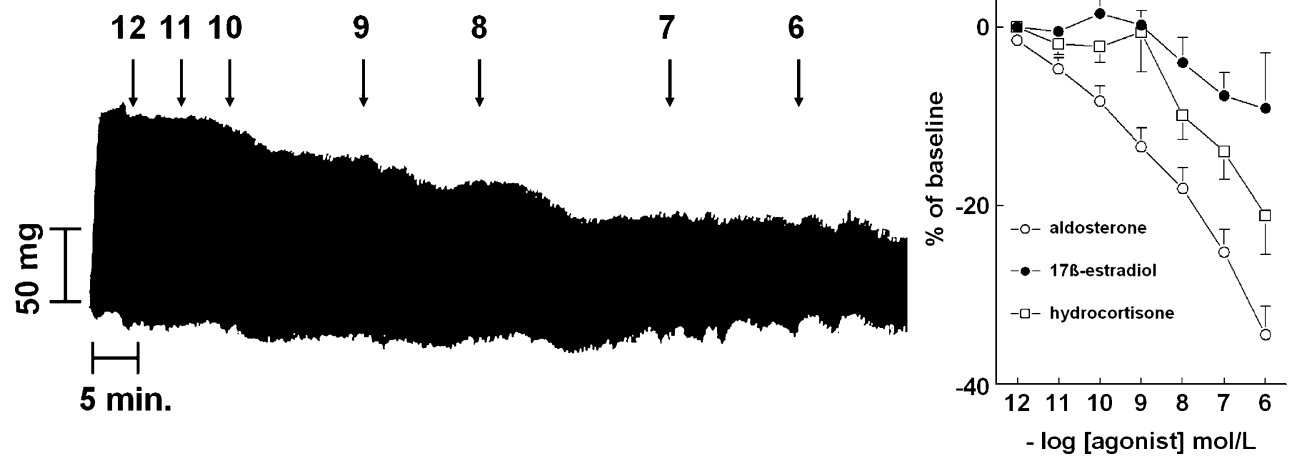

been observed on flow, either because such effects involve different cells, or because different second messengers are activated depending on the experimental circumstances (Barbato et al. 2004b; Chai et al. 2005a; Mihailidou et al. 2004; Schmidt et al. 2003). Finally, the consequences of PKC-induced regulation of $\mathrm{Na}^{+}-\mathrm{K}^{+}$pump activity are tissuespecific, and range from stimulation to inhibition, as described above (Mihailidou et al. 2004; Therien and Blostein 2000).

In human coronary arteries, aldosterone exerted no constrictor or dilator effect by itself. However, prior exposure to $1 \mu \mathrm{mol} / \mathrm{L}$ aldosterone greatly enhanced the constrictor response to Ang II (Chai et al. 2005b). At the second messenger level, this was reflected by an increase in the level of phosphorylated p42/p44 MAP kinase. Hydrocortisone and $17 \beta$-estradiol induced similar potentiating effects, but only in the case of aldosterone did these effects occur at the subnanomolar level, i.e., in a physiological range. Future investigations should now address to what degree this potentiation concerns aldosterone-induced endothelial dysfunction (Oberleithner 2005; Oberleithner et al. 2004), and/or an interaction with Ang II at the level of smooth muscle cells, involving some or all of the mediators that have recently been coupled to aldosterone, e.g., the PKC-IP 3 -DAG pathway, $\mathrm{Na}^{+} / \mathrm{H}^{+}$ exchange, $\mathrm{Na}^{+} / \mathrm{K}^{+}$-ATPase, p38 MAP kinase, ROS and/ or the epidermal growth factor receptor (Jaffe and Mendelsohn 2005; Liu et al. 2003; Mazak et al. 2004). Finally, the possibility of aldosterone-induced, endothelium-dependent, NO-mediated vasodilation, as proposed by several investigators (Liu et al. 2003; Schmidt et al. 2003), needs to be addressed.

\section{Arrhythmias}

MR blockade, in addition to standard therapy, reduced sudden death in RALES and EPHESUS (Pitt et al. 1999, 2003). The mechanism responsible for this favorable effect may rely on both renal changes in electrolyte excretion and myocardial fibrosis inhibition. In addition, conditional MR overexpression in the mouse heart, in the absence of aldosteronemia, has been reported to result in severe ventricular arrhythmias (Ouvrard-Pascaud et al. 2005). Apparently, cardiac MR trigger arrhythmias directly, thus providing an additional mechanism through which MR antagonists reduce sudden death in patients. In support of this possibility, spironolactone improved electrophysiological parameters such as QT interval dispersion (Yee et al. 2001), and, in combination with the ACE inhibitor fosinopril, reduced the arrhythmic score post-myocardial infarction (Beck et al. 2001).

Furthermore, both spironolactone and eplerenone improved the condition of the isolated perfused rat Langendorff heart following ischemia and reperfusion, as evidenced by a decrease in infarct size, a decrease in arrhythmia incidence, and an increase in left ventricular pressure recovery (Chai et al. 2005a, 2006) (Fig. 5). Given the virtual lack of aldosterone in the isolated perfused rat heart, it is unlikely that these effects are due to blockade of endogenous aldosterone. In fact, concomitant exposure to $100 \mathrm{nmol} / \mathrm{l}$ aldosterone did not further deteriorate the condition of the heart during ischaemia and reperfusion (Chai et al. 2006). A more likely explanation of these findings is therefore that spironolactone and eplerenone had blocked MR activation by endogenous glucocorticoids. Given the 1,000-fold higher levels of corticosterone in the rat heart (Gomez-Sanchez et al. 2004), and assuming that the washout of glucocorticoids resembles that of aldosterone, it can be calculated that, at the time of ischaemia, sufficient glucocorticoid levels are indeed present to allow cardiac MR activation. Such activation might occur particularly under conditions which facilitate ROS generation, such as ischaemia and reperfusion (Funder 2005b; Nagata et al. 2006). Interestingly in this regard, epidemiological observations have recently shown that high-dose corticosteroids increase the risk of developing atrial fibrillation (van der Hooft et al. 2006). The cardioprotective effect of MR antagonism in the 
Fig. 5 Infarct size (left panel), recovery of left ventricular pressure (LVP) (middle panel), and incidence of arrhythmias (right panel) in rat hearts that were subjected to $45 \mathrm{~min}$ left anterior descending coronary artery occlusion, followed by $3 \mathrm{~h}$ of reperfusion, after either no pretreatment $(\mathrm{C}$, control) or a 15 -min exposure to $100 \mathrm{nmol} / 1$ aldosterone $(A)$ $1 \mu \mathrm{mol} / 1$ spironolactone $(S)$, $1 \mu \mathrm{mol} / 1$ eplerenone $(E)$ or $100 \mathrm{nmol} / \mathrm{l}$ aldosterone $+1 \mu \mathrm{mol} /$ L eplerenone $(A+E)$. Data are from Chai et al. (2005a, 2006). $* P<0.05$ versus control

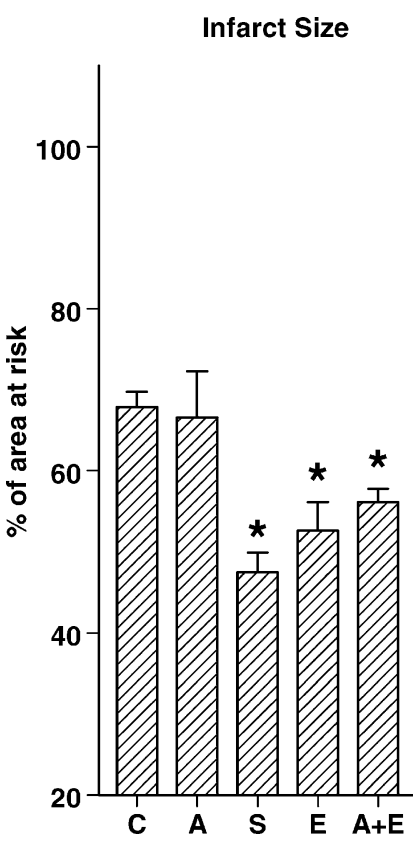

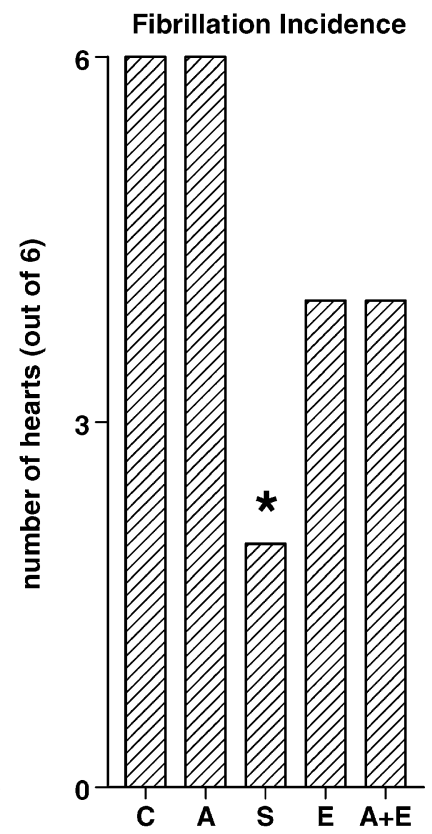

Langendorff heart during ischemia and reperfusion cannot be explained on the basis of the vasoconstrictor effect of aldosterone, as proposed by Fujita et al. (2005), since neither spironolactone nor eplerenone are capable of blocking aldosterone-induced vasoconstriction in vitro (Chai et al. 2005a, 2006).

Cardiac hypertrophy

Serum aldosterone levels associate with the variability of left ventricular mass (LVM) in both healthy controls and subjects with hypertension (Schunkert et al. 1997). The CYP11B2 C$344 \mathrm{~T}$ polymorphism associates with circulating aldosterone levels, subjects with the $\mathrm{T}$ allele having higher aldosterone levels than those with the $\mathrm{CC}$ genotype (Barbato et al. 2004a; Brand et al. 1998; Hautanena et al. 1998; Schunkert et al. 1999; Stella et al. 2004). Given the association between circulating aldosterone and LVM, it is not surprising that the $\mathrm{T}$ allele also associates with LVM, both in subjects with hypertension (Stella et al. 2004) and in patients with hypertrophic cardiomyopathy (Chai et al. 2005c). Interestingly, urinary $11 \beta$-HSD2 activity correlated directly with LVM in essential hypertension (Glorioso et al. 2005). This suggests that glucocorticoids also take part in the regulation of LVM. Furthermore, two independent investigations have shown that the CYP11B2 C-344T polymorphism is in strong linkage disequilibrium with polymorphisms of the nearby CYP11B1 gene (Ganapathipillai et al. 2005; Keavney et al. 2005). Since CYP11B1 (11ß-hydroxylase) is the enzyme catalyzing the final step in the biosynthesis of cortisol, the association with the C-344T polymorphism might not only
LVP Recovery

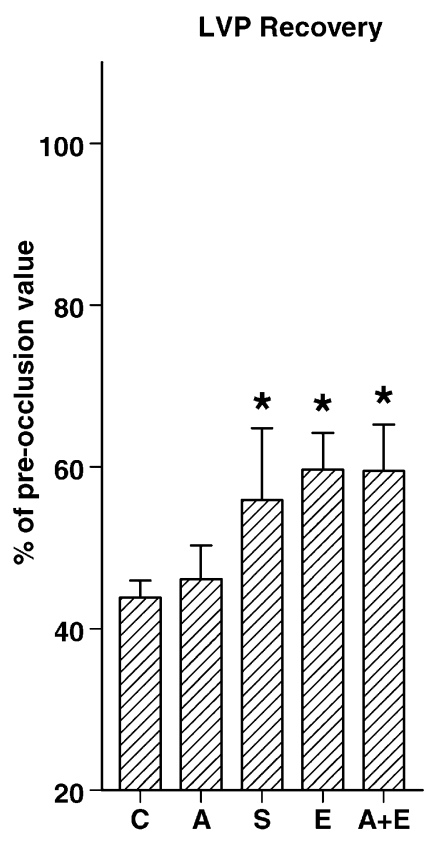

relate to increased aldosterone levels, but also to reduced $11 \beta$-hydroxylase activity (Hilgers and Schmidt 2005). Future studies, involving aldosterone, 11-deoxycortisol and cortisol measurements in serum and/or urine (White and Rainey 2005), should address this possibility.

Interaction with angiotensin II

Ang II stimulates the synthesis and release of aldosterone in the adrenal, and thus MR blockade and/or aldosterone synthase inhibition will exert beneficial effects in Ang IIdependent models (Fiebeler et al. 2005; Virdis et al. 2002). Remarkably, however, aldosterone also appears to exert its effects, at least in part, via Ang II (or its receptors), and both agonists, when applied together, act synergistically (Gonzalez et al. 2005; Mazak et al. 2004; Xiao et al. 2004) (Fig. 1). For instance, in cultured rat aortic smooth muscle cells, nanomolar concentrations of aldosterone enhanced the effect of Ang II on DNA synthesis (Chai et al. 2005a). Unexpectedly, higher (micromolar) aldosterone concentrations reduced DNA synthesis, both in smooth muscle cells and in cardiac myocytes. Such high aldosterone concentrations also reduced collagen synthesis in cardiac fibroblasts. These latter inhibitory effects most likely reflect glucocorticoid receptor activation by aldosterone (Arriza et al. 1987; Sato and Funder 1996). Furthermore, in human coronary artery smooth muscle cells, Ang II stimulated MR-mediated gene expression in an aldosterone-independent manner, suggesting direct MR activation by post-translational modifications such as phosphorylation (Jaffe and Mendelsohn 2005). 


\section{Clinical perspective: why are MR antagonists cardioprotective?}

The beneficial effects of MR antagonists in heart failure cannot be explained on the basis of their renal and/or blood pressure-lowering effects. Most likely they relate, at least in part, to blockade of a wide range of MR-mediated effects in the heart, including endothelial dysfunction, a decrease in cardiac inotropy and coronary flow, and the induction of fibrosis, hypertrophy, oxidative stress and arrhythmias. Some of these effects occur via or in synergy with Ang II. Given the virtual absence of aldosterone production in the heart, and in view of the low cardiac levels of the cortisolinactivating enzyme $11 \beta$-HSD2, it is unlikely that, under all conditions, aldosterone is the endogenous agonist of cardiac MR. Thus, some of the MR-mediated effects in the heart may be due to MR activation by glucocorticoids, particularly when ROS levels are high. The aldosterone levels in the failing human heart, but not those in the healthy heart, are high enough to be of functional importance. Whether some of the above (acute, 'non-genomic') in vitro effects of aldosterone are mediated via a non-MR-mediated mechanism remains to be proven, in particular because no (membrane receptor) candidate has been identified so far that induces these effects. If true, however, aldosterone synthase inhibitors might be expected to exert beneficial effects on top of MR blockade.

\section{References}

Abiose AK, Mansoor GA, Barry M, Soucier R, Nair CK, Hager D (2004) Effect of spironolactone on endothelial function in patients with congestive heart failure on conventional medical therapy. Am J Cardiol 93:1564-1566

Ahokas RA, Sun Y, Bhattacharya SK, Gerling IC, Weber KT (2005) Aldosteronism and a proinflammatory vascular phenotype: role of $\mathrm{Mg} 2+, \mathrm{Ca} 2+$, and $\mathrm{H} 2 \mathrm{O} 2$ in peripheral blood mononuclear cells. Circulation 111:51-57

Alzamora R, Michea L, Marusic ET (2000) Role of 11 betahydroxysteroid dehydrogenase in nongenomic aldosterone effects in human arteries. Hypertension 35:1099-1104

Arriza JL, Weinberger C, Cerelli G, Glaser TM, Handelin BL, Housman DE, Evans RM (1987) Cloning of human mineralocorticoid receptor complementary DNA: structural and functional kinship with the glucocorticoid receptor. Science 237:268-275

Barbato A, Russo P, Siani A, Folkerd EJ, Miller MA, Venezia A, Grimaldi C, Strazzullo P, Cappuccio FP (2004a) Aldosterone synthase gene (CYP11B2) C-344T polymorphism, plasma aldosterone, renin activity and blood pressure in a multi-ethnic population. J Hypertens 22:1895-1901

Barbato JC, Mulrow PJ, Shapiro JI, Franco-Saenz R (2002) Rapid effects of aldosterone and spironolactone in the isolated working rat heart. Hypertension 40:130-135

Barbato JC, Rashid S, Mulrow PJ, Shapiro JI, Franco-Saenz R (2004b) Mechanisms for aldosterone and spironolactone-induced positive inotropic actions in the rat heart. Hypertension 44:751757
Batenburg WW, Garrelds IM, Bernasconi CC, Juillerat-Jeanneret L, van Kats JP, Saxena PR, Danser AHJ (2004) Angiotensin II type 2 receptor-mediated vasodilation in human coronary microarteries. Circulation 109:2296-2301

Beck L, Blanc-Guillemaud V, Cherif OK, Jover B, Davy JM (2001) Effects of spironolactone and fosinopril on the spontaneous and chronic ventricular arrhythmias in a rat model of myocardial infarction. Cardiology 96:85-93

Blasi ER, Rocha R, Rudolph AE, Blomme EA, Polly ML, McMahon EG (2003) Aldosterone/salt induces renal inflammation and fibrosis in hypertensive rats. Kidney Int 63:1791-1800

Brand E, Chatelain N, Mulatero P, Fery I, Curnow K, Jeunemaitre X, Corvol P, Pascoe L, Soubrier F (1998) Structural analysis and evaluation of the aldosterone synthase gene in hypertension. Hypertension 32:198-204

Brilla CG, Zhou G, Matsubara L, Weber KT (1994) Collagen metabolism in cultured adult rat cardiac fibroblasts: response to angiotensin II and aldosterone. J Mol Cell Cardiol 26:809-820

Caballero R, Moreno I, Gonzalez T, Arias C, Valenzuela C, Delpon E, Tamargo J (2003) Spironolactone and its main metabolite, canrenoic acid, block human ether-a-go-go-related gene channels. Circulation 107:889-895

Calo LA, Zaghetto F, Pagnin E, Davis PA, De Mozzi P, Sartorato P, Martire G, Fiore C, Armanini D (2004) Effect of aldosterone and glycyrrhetinic acid on the protein expression of PAI-1 and p22 (phox) in human mononuclear leukocytes. J Clin Endocrinol Metab 89:1973-1976

Cargnelli G, Trevisi L, Debetto P, Luciani S, Bova S (2001) Effects of canrenone on aorta and right ventricle of the rat. J Cardiovasc Pharmacol 37:540-547

Casal AJ, Silvestre JS, Delcayre C, Capponi AM (2003) Expression and modulation of steroidogenic acute regulatory protein messenger ribonucleic acid in rat cardiocytes and after myocardial infarction. Endocrinology 144:1861-1868

Chai W, Garrelds IM, Arulmani U, Schoemaker RG, Lamers JMJ, Danser AHJ (2005a) Genomic and non-genomic effects of aldosterone in the rat heart: why is spironolactone cardioprotective? Br J Pharmacol 145:664-671

Chai W, Garrelds IM, de Vries R, Batenburg WW, van Kats JP, Danser AHJ (2005b) Nongenomic effects of aldosterone in the human heart. Interaction with Angiotensin II. Hypertension 46:701-706

Chai W, van Schaik RHN, van Fessem MA, Kofflard MJM, ten Cate FJ, Danser AHJ (2005c) Aldosterone and cardiac hypertrophy in subjects with hypertrophic cardiomyopathy. Circulation 112 (suppl II):356 (Abstract)

Chai W, Garrelds IM, de Vries R, Danser AHJ (2006) Cardioprotective effects of eplerenone in the rat heart: interaction with locally synthesized or blood-derived aldosterone? Hypertension 47:665-670

Danser AHJ (2003) Local renin-angiotensin systems: the unanswered questions. Int J Biochem Cell Biol 35:759-768

Danser AHJ, van Kats JP, Admiraal PJJ, Derkx FHM, Lamers JMJ, Verdouw PD, Saxena PR, Schalekamp MADH (1994) Cardiac renin and angiotensins. Uptake from plasma versus in situ synthesis. Hypertension 24:37-48

Danser AHJ, van Kesteren CAM, Bax WA, Tavenier M, Derkx FHM, Saxena PR, Schalekamp MADH (1997) Prorenin, renin, angiotensinogen, and angiotensin-converting enzyme in normal and failing human hearts. Evidence for renin binding. Circulation 96:220-226

de Kloet ER, van Acker SA, Sibug RM, Oitzl MS, Meijer OC, Rahmouni K, de Jong W (2000) Brain mineralocorticoid receptors and centrally regulated functions. Kidney Int 57:1329-1336

de Lannoy LM, Danser AHJ, van Kats JP, Schoemaker RG, Saxena PR, Schalekamp MADH (1997) Renin-angiotensin system 
components in the interstitial fluid of the isolated perfused rat heart. Local production of angiotensin I. Hypertension 29:1240 1251

Farquharson CA, Struthers AD (2002) Gradual reactivation over time of vascular tissue angiotensin I to angiotensin II conversion during chronic lisinopril therapy in chronic heart failure. J Am Coll Cardiol 39:767-775

Fiebeler A, Nussberger J, Shagdarsuren E, Rong S, Hilfenhaus G, AlSaadi N, Dechend R, Wellner M, Meiners S, Maser-Gluth C, Jeng AY, Webb RL, Luft FC, Müller DN (2005) Aldosterone synthase inhibitor ameliorates angiotensin II-induced organ damage. Circulation 111:3087-3094

Fujita M, Minamino T, Asanuma H, Sanada S, Hirata A, Wakeno M, Myoishi M, Okuda H, Ogai A, Okada K, Tsukamoto O, Koyama $\mathrm{H}$, Hori M, Kitakaze M (2005) Aldosterone nongenomically worsens ischemia via protein kinase C-dependent pathways in hypoperfused canine hearts. Hypertension 46:113-117

Funder JW (2005a) The nongenomic actions of aldosterone. Endocr Rev 26:313-321

Funder JW (2005b) RALES, EPHESUS and redox. J Steroid Biochem Mol Biol 93:121-125

Ganapathipillai S, Laval G, Hoffmann IS, Castejon AM, Nicod J, Dick B, Frey FJ, Frey BM, Cubeddu LX, Ferrari P (2005) CYP11B2-CYP11B1 haplotypes associated with decreased 11 beta-hydroxylase activity. J Clin Endocrinol Metab 90:1220 1225

Glorioso N, Filigheddu F, Parpaglia PP, Soro A, Troffa C, Argiolas G, Mulatero P (2005) 11beta-Hydroxysteroid dehydrogenase type 2 activity is associated with left ventricular mass in essential hypertension. Eur Heart J 26:498-504

Gomez-Sanchez CE, Zhou MY, Cozza EN, Morita H, Foecking MF, Gomez-Sanchez EP (1997) Aldosterone biosynthesis in the rat brain. Endocrinology 138:3369-3373

Gomez-Sanchez EP, Ahmad N, Romero DG, Gomez-Sanchez CE (2004) Origin of aldosterone in the rat heart. Endocrinology 145:4796-4802

Gonzalez M, Lobos L, Castillo F, Galleguillos L, Lopez NC, Michea L (2005) High-salt diet inhibits expression of angiotensin type 2 receptor in resistance arteries. Hypertension 45:853-859

Good DW, George T, Watts BA 3rd (2002) Aldosterone inhibits HCO absorption via a nongenomic pathway in medullary thick ascending limb. Am J Physiol Renal Physiol 283:F699-706

Hagendorf A, Koper JW, de Jong FH, Brinkmann AO, Lamberts SWJ, Feelders RA (2005) Expression of the human glucocorticoid receptor splice variants alpha, beta, and $\mathrm{P}$ in peripheral blood mononuclear leukocytes in healthy controls and in patients with hyper- and hypocortisolism. J Clin Endocrinol Metab 90:62376243

Hautanena A, Lankinen L, Kupari M, Janne OA, Adlercreutz H, Nikkila H, White PC (1998) Associations between aldosterone synthase gene polymorphism and the adrenocortical function in males. J Intern Med 244:11-18

Hayashi M, Tsutamoto T, Wada A, Tsutsui T, Ishii C, Ohno K, Fujii M, Taniguchi A, Hamatani T, Nozato Y, Kataoka K, Morigami N, Ohnishi M, Kinoshita M, Horie M (2003) Immediate administration of mineralocorticoid receptor antagonist spironolactone prevents post-infarct left ventricular remodeling associated with suppression of a marker of myocardial collagen synthesis in patients with first anterior acute myocardial infarction. Circulation 107:2559-2565

Hilgers KF, Schmidt BM (2005) Gene variants of aldosterone synthase and hypertension. J Hypertens 23:1957-1959

Jaffe IZ, Mendelsohn ME (2005) Angiotensin II and aldosterone regulate gene transcription via functional mineralocortocoid receptors in human coronary artery smooth muscle cells. Circ Res 96:643-650
Jorde UP, Vittorio T, Katz SD, Colombo PC, Latif F, Le Jemtel TH (2002) Elevated plasma aldosterone levels despite complete inhibition of the vascular angiotensin-converting enzyme in chronic heart failure. Circulation 106:1055-1057

Keavney B, Mayosi B, Gaukrodger N, Imrie H, Baker M, Fraser R, Ingram M, Watkins H, Farrall M, Davies E, Connell J (2005) Genetic variation at the locus encompassing 11-beta hydroxylase and aldosterone synthase accounts for heritability in cortisol precursor (11-deoxycortisol) urinary metabolite excretion. J Clin Endocrinol Metab 90:1072-1077

Liu SL, Schmuck S, Chorazcyzewski JZ, Gros R, Feldman RD (2003) Aldosterone regulates vascular reactivity: short-term effects mediated by phosphatidylinositol 3-kinase-dependent nitric oxide synthase activation. Circulation 108:2400-2406

Lombès M, Oblin ME, Gasc JM, Baulieu EE, Farman N, Bonvalet JP (1992) Immunohistochemical and biochemical evidence for a cardiovascular mineralocorticoid receptor. Circ Res 71:503-510

Lombès M, Kenouch S, Souque A, Farman N, Rafestin-Oblin ME (1994) The mineralocorticoid receptor discriminates aldosterone from glucocorticoids independently of the 11 beta-hydroxysteroid dehydrogenase. Endocrinology 135:834-840

Lombès M, Alfaidy N, Eugene E, Lessana A, Farman N, Bonvalet JP (1995) Prerequisite for cardiac aldosterone action. Mineralocorticoid receptor and 11 beta-hydroxysteroid dehydrogenase in the human heart. Circulation 92:175-182

Lösel R, Feuring M, Wehling M (2002) Non-genomic aldosterone action: from the cell membrane to human physiology. J Steroid Biochem Mol Biol 83:167-171

Macdonald JE, Kennedy N, Struthers AD (2004) Effects of spironolactone on endothelial function, vascular angiotensin converting enzyme activity, and other prognostic markers in patients with mild heart failure already taking optimal treatment. Heart 90:765-770

Mazak I, Fiebeler A, Müller DN, Park JK, Shagdarsuren E, Lindschau C, Dechend R, Viedt C, Pilz B, Haller H, Luft FC (2004) Aldosterone potentiates angiotensin II-induced signaling in vascular smooth muscle cells. Circulation 109:2792-2800

Michea L, Delpiano AM, Hitschfeld C, Lobos L, Lavandero S, Marusic ET (2005) Eplerenone blocks nongenomic effects of aldosterone on the $\mathrm{Na}+\mathrm{H}+$ exchanger, intracellular $\mathrm{Ca} 2+$ levels, and vasoconstriction in mesenteric resistance vessels. Endocrinology 146:973-980

Mihailidou AS, Mardini M, Funder JW (2004) Rapid, nongenomic effects of aldosterone in the heart mediated by epsilon protein kinase C. Endocrinology 145:773-780

Moreau D, Chardigny JM, Rochette L (1996) Effects of aldosterone and spironolactone on the isolated perfused rat heart. Pharmacology 53:28-36

Nagata K, Obata K, Xu J, Ichihara S, Noda A, Kimata H, Kato T, Izawa H, Murohara T, Yokota M (2006) Mineralocorticoid receptor antagonism attenuates cardiac hypertrophy and failure in low-aldosterone hypertensive rats. Hypertension 47:656-664

Nakamura S, Yoshimura M, Nakayama M, Ito T, Mizuno Y, Harada E, Sakamoto T, Saito Y, Nakao K, Yasue H, Ogawa H (2004) Possible association of heart failure status with synthetic balance between aldosterone and dehydroepiandrosterone in human heart. Circulation 110:1787-1793

Oberleithner H (2005) Aldosterone makes human endothelium stiff and vulnerable. Kidney Int 67:1680-1682

Oberleithner H, Ludwig T, Riethmuller C, Hillebrand U, Albermann L, Schafer C, Shahin V, Schillers H (2004) Human endothelium: target for aldosterone. Hypertension 43:952-956

Ouvrard-Pascaud A, Sainte-Marie Y, Benitah JP, Perrier R, Soukaseum C, Cat AN, Royer A, Le Quang K, Charpentier F, Demolombe S, Mechta-Grigoriou F, Beggah AT, Maison-Blanche P, Oblin ME, Delcayre C, Fishman GI, Farman N, Escoubet B, Jaisser F (2005) 
Conditional mineralocorticoid receptor expression in the heart leads to life-threatening arrhythmias. Circulation 111:3025-3033

Pitt B, Zannad F, Remme WJ, Cody R, Castaigne A, Perez A, Palensky J, Wittes J (1999) The effect of spironolactone on morbidity and mortality in patients with severe heart failure. Randomized Aldactone Evaluation Study Investigators. N Engl J Med 341:709-717

Pitt B, Remme W, Zannad F, Neaton J, Martinez F, Roniker B, Bittman R, Hurley S, Kleiman J, Gatlin M (2003) Eplerenone, a selective aldosterone blocker, in patients with left ventricular dysfunction after myocardial infarction. N Engl J Med 348:1309-1321

Qin W, Rudolph AE, Bond BR, Rocha R, Blomme EA, Goellner JJ, Funder JW, McMahon EG (2003) Transgenic model of aldosteronedriven cardiac hypertrophy and heart failure. Circ Res 93:69-76

Saris JJ, Derkx FHM, de Bruin RJA, Dekkers DHW, Lamers JMJ, Saxena PR, Schalekamp MADH, Danser AHJ (2001) High-affinity prorenin binding to cardiac man-6-P/IGF-II receptors precedes proteolytic activation to renin. Am J Physiol 280:H1706-H1715

Sato A, Funder JW (1996) High glucose stimulates aldosteroneinduced hypertrophy via type I mineralocorticoid receptors in neonatal rat cardiomyocytes. Endocrinology 137:4145-4153

Sato A, Liu JP, Funder JW (1997) Aldosterone rapidly represses protein kinase $\mathrm{C}$ activity in neonatal rat cardiomyocytes in vitro. Endocrinology 138:3410-3416

Schmidt BMW, Oehmer S, Delles C, Bratke R, Schneider MP, Klingbeil A, Fleischmann EH, Schmieder RE (2003) Rapid nongenomic effects of aldosterone on human forearm vasculature. Hypertension 42:156-160

Schunkert H, Hense HW, Muscholl M, Luchner A, Kürzinger S, Danser AHJ, Riegger GA (1997) Associations between circulating components of the renin-angiotensin-aldosterone system and left ventricular mass. Heart 77:24-31

Schunkert H, Hengstenberg C, Holmer SR, Broeckel U, Luchner A, Muscholl MW, Kurzinger S, Doring A, Hense HW, Riegger GA (1999) Lack of association between a polymorphism of the aldosterone synthase gene and left ventricular structure. Circulation 99:2255-2260

Silvestre JS, Robert V, Heymes C, Aupetit-Faisant B, Mouas C, Moalic JM, Swynghedauw B, Delcayre C (1998) Myocardial production of aldosterone and corticosterone in the rat. Physiological regulation. J Biol Chem 273:4883-4891

Stella P, Bigatti G, Tizzoni L, Barlassina C, Lanzani C, Bianchi G, Cusi D (2004) Association between aldosterone synthase (CYP11B2) polymorphism and left ventricular mass in human essential hypertension. J Am Coll Cardiol 43:265-270

Sun Y, Zhang J, Lu L, Chen SS, Quinn MT, Weber KT (2002) Aldosterone-induced inflammation in the rat heart: role of oxidative stress. Am J Pathol 161:1773-1781

Suzuki J, Iwai M, Mogi M, Oshita A, Yoshii T, Higaki J, Horiuchi M (2006) Eplerenone with valsartan effectively reduces atherosclerotic lesion by attenuation of oxidative stress and inflammation. Arterioscler Thromb Vasc Biol 26:917-921

Takai S, Jin D, Muramatsu M, Kirimura K, Sakonjo H, Miyazaki M (2005) Eplerenone inhibits atherosclerosis in nonhuman primates. Hypertension 46:1135-1139

Takeda Y, Miyamori I, Yoneda T, Iki K, Hatakeyama H, Blair IA, Hsieh FY, Takeda R (1995) Production of aldosterone in isolated rat blood vessels. Hypertension 25:170-173
Takeda Y, Miyamori I, Inaba S, Furukawa K, Hatakeyama H, Yoneda T, Mabuchi H, Takeda R (1997) Vascular aldosterone in genetically hypertensive rats. Hypertension 29:45-48

Takeda Y, Yoneda T, Demura M, Miyamori I, Mabuchi H (2000) Cardiac aldosterone production in genetically hypertensive rats. Hypertension 36:495-500

Therien AG, Blostein R (2000) Mechanisms of sodium pump regulation. Am J Physiol Cell Physiol 279:C541-566

Tom B, Garrelds IM, Scalbert E, Stegmann APA, Boomsma F, Saxena PR, Danser AHJ (2003) ACE- versus chymase-dependent angiotensin II generation in human coronary arteries: a matter of efficiency? Arterioscler Thromb Vasc Biol 23:251-256

Tsybouleva N, Zhang L, Chen S, Patel R, Lutucuta S, Nemoto S, DeFreitas G, Entman M, Carabello BA, Roberts R, Marian AJ (2004) Aldosterone, through novel signaling proteins, is a fundamental molecular bridge between the genetic defect and the cardiac phenotype of hypertrophic cardiomyopathy. Circulation 109:1284-1291

van der Hooft CS, Sturkenboom MC, van Grootheest K, Kingma HJ, Stricker BH (2006) Adverse drug reaction-related hospitalisations: a nationwide study in The Netherlands. Drug Saf 29:161-168

van Kats JP, Danser AHJ, van Meegen JR, Sassen LM, Verdouw PD, Schalekamp MADH (1998) Angiotensin production by the heart: a quantitative study in pigs with the use of radiolabeled angiotensin infusions. Circulation 98:73-81

van Kats JP, Duncker DJ, Haitsma DB, Schuijt MP, Niebuur R, Stubenitsky R, Boomsma F, Schalekamp MADH, Verdouw PD, Danser AHJ (2000) Angiotensin-converting enzyme inhibition and angiotensin II type 1 receptor blockade prevent cardiac remodeling in pigs after myocardial infarction: role of tissue angiotensin II. Circulation 102:1556-1563

Virdis A, Neves MF, Amiri F, Viel E, Touyz RM, Schiffrin EL (2002) Spironolactone improves angiotensin-induced vascular changes and oxidative stress. Hypertension 40:504-510

Wehling M (2005) Effects of aldosterone and mineralocorticoid receptor blockade on intracellular electrolytes. Heart Fail Rev 10:39-46

Wehling M, Neylon CB, Fullerton M, Bobik A, Funder JW (1995) Nongenomic effects of aldosterone on intracellular $\mathrm{Ca} 2+$ in vascular smooth muscle cells. Circ Res 76:973-979

White PC, Rainey WE (2005) Editorial: polymorphisms in CYP11B genes and 11-hydroxylase activity. J Clin Endocrinol Metab 90:1252-1255

Xiao F, Puddefoot JR, Barker S, Vinson GP (2004) Mechanism for aldosterone potentiation of angiotensin II-stimulated rat arterial smooth muscle cell proliferation. Hypertension 44:340-345

Yee KM, Pringle SD, Struthers AD (2001) Circadian variation in the effects of aldosterone blockade on heart rate variability and QT dispersion in congestive heart failure. J Am Coll Cardiol 37:1800-1807

Young MJ, Clyne CD, Cole TJ, Funder JW (2001) Cardiac steroidogenesis in the normal and failing heart. J Clin Endocrinol Metab 86:5121-5126

Yusuf S, Sleight P, Pogue J, Bosch J, Davies R, Dagenais G (2000) Effects of an angiotensin-converting-enzyme inhibitor, ramipril, on cardiovascular events in high-risk patients. The Heart Outcomes Prevention Evaluation Study Investigators. N Engl J Med 342:145-153 